\title{
Antiproliferation activity of God's crown fruit (Phaleria macrocarpa) extract and fractions against MCM-B2 breast cancer cells
}

\author{
Hasim Hasim $^{1 *}$, Silvi Octavia Kurniawati ${ }^{1}$, Bambang Pontjo Priosoeryanto ${ }^{2}$, Didah Nur Faridah ${ }^{3}$, Ratna Puspita ${ }^{1}$ \\ ${ }^{1}$ Department of Biochemistry, Faculty of Mathematics and Natural Sciences, IPB University, Bogor 16680, Indonesia. \\ ${ }^{2}$ Department of Veterinary Clinic, Reproduction and Pathology, Faculty of Veterinary Medicine, IPB University, Bogor 16680, Indonesia. \\ ${ }^{3}$ Department of Food Science and Technology, Faculty of Agricultural Engineering and Technology, IPB University, Bogor 16680, Indonesia.
}

\begin{tabular}{|c|c|}
\hline ARTICLE INFO & ABSTRACT \\
\hline $\begin{array}{l}\text { Received on: } 15 / 10 / 2019 \\
\text { Accepted on: } 25 / 12 / 2019 \\
\text { Available online: } 05 / 03 / 2020\end{array}$ & $\begin{array}{l}\text { Breast cancer is a disease caused by abnormal cell proliferation in the breast. God's crown fruit (Phaleria macrocarpa) } \\
\text { and its seed have potential as an antiproliferation of cancer cells. It contains active compounds such as flavonoids, } \\
\text { alkaloids, polyphenols, and tannins. The sample of God's crown fruit was obtained by extraction and fractionation } \\
\text { using the maceration method. Cytotoxicity of extracts and fractions was determined using Brine Shrimp Lethality Test }\end{array}$ \\
\hline $\begin{array}{l}\text { Key words: } \\
\text { Antiproliferation, breast } \\
\text { cancer, cytotoxicity, } \\
\text { MCM-B2 cells, Phaleria } \\
\text { macrocarpa. }\end{array}$ & $\begin{array}{l}\text { method. Antiproliferation activity test of God's crown fruit against MCM-B2 was performed using the hemacytometer } \\
\text { method. The God's crown fruit sample consists of crude ethanol extract, n-hexane fraction, ethyl acetate fraction, and } \\
\text { water fraction. Lethal concentration } 50\left(\mathrm{LC}_{50}\right) \text { values in crude ethanol extract, n-hexane fraction, ethyl acetate fraction, } \\
\text { and water fraction were } 13.72,147.55,405.81 \text {, and } 149.55 \mathrm{ppm} \text {, respectively. The concentration of the test sample was } \\
\text { directly used for the antiproliferation activity test on MCM-B2 cells. God's crown fruit can act as antiproliferation of } \\
\text { MCM-B2. The smallest concentration of those samples has inhibited MCM-B2 cell proliferation which is } 3.5 \mathrm{ppm} \\
\text { crude ethanol extract lower than } 100 \mathrm{ppm} \text { doxorubicin. The maximum percentage of the antiproliferation activity of } \\
\text { crude ethanol extract ( } 56 \mathrm{ppm}) \text { was able to inhibit MCM-B2 cell proliferation by } 58.28 \% \text { while doxorubicin ( } 100 \mathrm{ppm}) \\
\text { by } 31.2 \% \text {. This is due to the fact that crude ethanol extract has a lot of complex polar phytochemical content. The crude } \\
\text { ethanol extract compounds inhibit MCM-B2 cell proliferation synergistically. }\end{array}$ \\
\hline
\end{tabular}

\section{INTRODUCTION}

Cancer is caused by abnormal cell growth (proliferation) or genetic mutation. Cancer cells spread to other organs (Sulaiman et al., 2019). Factors triggering the proliferation abnormality in body cells are: exposure to chemicals (carcinogens), heredity, radiation, viruses, consumption of foods containing carcinogens, and lack of consumption of fruits and vegetables. The food types containing high fat and protein processed with high temperatures are one of the consumption of foods that trigger cancer. Consumption of fruits and vegetables which contain antioxidants helps the body to process the proliferation of natural killer lymphocyte cells that can lyse cancer cells (Agustinisari and Zakaria, 2019).

\footnotetext{
${ }^{*}$ Corresponding Author

Hasim Hasim, Department of Biochemistry, Faculty of Mathematics and Natural Sciences, IPB University, Bogor 16680, Indonesia.

E-mail: hasimdea@yahoo.com
}

Cancer can occur in various organs of the body, one of them in the breast. Breast cancer can start from the formation of abnormal lumps, namely tumors. One type of breast tumor cell can be isolated from the mammary glands of a 10 -year-old female $\operatorname{dog}$ (MCM-B2). These tumor cells originate from stem cells or atypical cells (Priosoeryanto et al., 1995).

Breast cancer is the second most common cancer that causes death in women (Wardhani et al., 2016). In 2017, it is predicted that breast cancer sufferers worldwide will reach 6,232,108 cases. In 2012, there were 521,907 deaths worldwide due to breast cancer (Malik et al., 2018). According to Sunaryo (2018), the percentage of breast cancer cases in women in the world reached $43.3 \%$ and the percentage of deaths from breast cancer reached $12.9 \%$. The success rate of preventing cancer deaths in 2015 reached $30 \%-50 \%$. Prevention of cancer deaths can be done by identifying the type of cancer until it can prevent its spread earlier (Ma'aruf et al., 2018). 
The God's crown (Phaleria macrocarpa) is a medicinal plant that is suspected to have antiproliferation activity in cancer cells. The God's crown is classified as a shrub plant from the Thymelaeaceae tribe. God's crown plant can flourish in the lowlands to a height of 1,200 $\mathrm{m}$ above sea level (Setyawan et al., 2018). In Indonesia, God's crown plant grows in its original habitat, namely in the area of Papua. Cultivation of God's crown plant can be done vegetatively or generatively. The easy cultivation process and characteristics of God's crown plants that can grow well in various regions of Indonesia have a high potential to be developed (Lukmandaru and Gazidy, 2016).

The flesh and seed shell of God's crown fruit shown in Figure 1 contain many metabolites such as secondary metabolites. It contains alkaloids, flavonoids, polyphenol compounds, and tannins (Setyawan et al., 2018). The flesh of God's crown fruit is the highest content of flavonoid compounds compared to other parts (Setyawan et al., 2018). Flavonoids are classified as natural phenolic compounds which have the potential to become antioxidants and have bioactivity as medicines (Rohyami, 2008).

The traditional usage of God's crown fruit is generally by consuming a single or together with other traditional medicines. God's crown fruit is generally boiled. Therefore, research needs to be carried out on the effectiveness of antiproliferation potential of God's crown fruit and seed shell on MCM-B2 until it can be used as an alternative treatment for breast cancer.

\section{MATERIALS AND METHODS}

\section{Materials}

The materials used in the study are the flesh and seed shell of God's crown fruit (Phaleria macrocarpa) obtained from Lulut Citeureup village, 70\% ethanol, 95\% ethanol, Artemia salina shrimp larvae eggs, n-hexane, ethyl acetate, distilled water, sea water, MCM-B2 cells, Dulbecco's Modified Eagle's Medium (DMEM), phenol red, gentamicin, fungizone, fetal bovine serum (FBS), dimethyl sulfoxide (DMSO), doxorubicin, and trypan blue.

\section{God's crown fruit preparation}

God's crown fruit preparation was conducted according to the modified method of Dawud et al. (2014). God's crown fruit was washed with running water until clean. The fruit is cut into pieces and separated from the seeds. Pieces of fruit are dried in an oven at $40^{\circ} \mathrm{C}-50^{\circ} \mathrm{C}$ for 5 days until all parts are dried. Dried fruit is blended until smooth and the simplisia of God's crown fruit is obtained.

Simplisia water content was measured using the gravimetric method of (Martono et al., 2016). Porcelain cup and

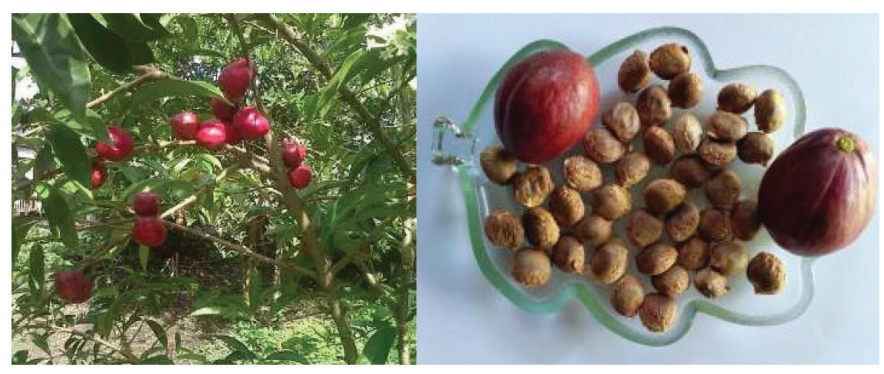

Figure 1. Fruits and seeds of God's crown plant. lid are washed and dried first and roasted for 15 minutes at $105^{\circ} \mathrm{C}$. After the oven, the porcelain cup and lid are then placed in a desiccator for 15 minutes in the open position. The cup and lid are weighed empty. Then, the sample is weighed as much as $2 \mathrm{~g}$ and put into a porcelain cup. Porcelain dishes containing samples were covered and roasted for 3 hours at $105^{\circ} \mathrm{C}$. The cup is put into the desiccator for 30 minutes until it is cold and weighed after heating.

The extraction of sample was conducted according to the modified method of Ramadhan et al. (2019). Sample extraction was carried out by maceration method and using 96\% ethanol solvent. Comparison of sample to solvent used is $60 \mathrm{~g}$ of sample in $500 \mathrm{ml}$ of solvent. The sample was weighed as much as $60 \mathrm{~g}$ and put into an Erlenmeyer and added 96\% ethanol 96\% solvent. The sample mixture and solvent are stirred slowly and covered with aluminum foil. The mixture is stored at room temperature for 3 days. After 3 days, the mixture is filtered using vacuum and filter paper. Then, the maceration is repeated using the same procedure. The first and second filtered filtrate are combined and evaporated using a rotary evaporator at a temperature of $50^{\circ} \mathrm{C}$ at a speed of $110 \mathrm{rpm}$ until a concentrated crude ethanol extract is obtained.

Fractionation of crude ethanol extract was conducted according to the modified method of Rinayanti et al. (2014). The fractionation of crude ethanol extract was carried out in stages using the liquid-liquid method. The solvents used in the fractionation are n-hexane, ethyl acetate, and distilled water. Crude ethanol extract was weighed as much as $5 \mathrm{~g}$ and dissolved with $\mathrm{n}$-hexane as much as $50 \mathrm{ml}$ in a beaker. The mixture is homogeneous by stirring using a spatula and sonified for 30 minutes. After sonification, the n-hexane liquid from the sonification results is put into a separating funnel and the yield remain in the goblet. The yield remaining in the beaker are added with $50 \mathrm{ml}$ of distilled water.

Mix the precipitate mixture with distilled water for 30 minutes. The liquid distilled water after being inserted is inserted into a separating funnel that already contains the previous n-hexane fraction. The mixture of $n$-hexane fraction with water fraction is shaken in a separating funnel and let stand for 30 minutes. After settling, it will form a layer of aquades fraction at the bottom and $n$-hexane fraction at the top. Separate the n-hexane fraction and reenter the aquades fraction into the separating funnel. Glass cup that still contains the precipitate of the previous yield filled with n-hexane as much as $50 \mathrm{ml}$ and carried out the same process three times repetition. The same procedure was carried out with ethyl acetate and aquades solvents until ethyl acetate and aquades fractions were obtained. The n-hexane fraction, ethyl acetate fraction, and aquades fraction were concentrated and evaporated using a rotary evaporator until a concentrated fraction is obtained.

\section{Cytotoxicity test}

Cytotoxicity test by Brine Shrimp Lethality Test of sample was conducted according to the modified method of Tulangow et al. (2016).

Artemia salina larvae preparation

Artemia salina larvae weighed $1 \mathrm{~g}$ and put in a glass container containing $100 \mathrm{ml}$ of sea water. Artemia salina eggs are allowed to sit under the light and are given an air supply through an aerator. The hatching of Artemia salina eggs is carried out in 48 hours. 


\section{Sample solution preparation}

The samples of crude ethanol extract, n-hexane fraction, ethyl acetate fraction, and water fraction were weighed $0.25 \mathrm{~g}$ each in a beaker. As much as $15 \mathrm{ml}$ of sea water is put into each cup containing the sample and homogenized using a magnetic stirrer until the sample is completely dissolved. After being homogeneous, the solution is put into a $25 \mathrm{ml}$ measuring flask and signed with sea water so that a stock solution with a concentration of $25,000 \mathrm{ppm}$ is obtained. The stock solution of each sample is then diluted to obtain test solutions with concentrations of 100 , $200,400,600,800$, and 1,000 ppm.

\section{Testing against Artemia salina larvae}

Seawater is put into the microplate well as much as $2 \mathrm{ml}$. Larvae that have been hatched in a glass container inserted into the microplate hole as many as 10 heads in each well. The test solution that has been made is put into a microplate well as much as $0.5 \mathrm{ml}$ and affirmed up to $5 \mathrm{ml}$. Each concentration in each sample of the test solution was repeated three times. Then, incubated at room temperature for 24 hours. After 24 hours, the number of dead larvae was calculated and analyzed for lethal concentration 50 $\left(\mathrm{LC}_{50}\right)$ values using the Minitab program.

\section{Antiproliferation activity test against MCM-B2 cells}

Antiproliferation activity test of the sample was conducted according to the modified method of Priosoeryanto et al. (1995).

\section{Making media grow}

DMEM (the DMEM formula composition contains 1,000 $\mathrm{mg} / \mathrm{l}$ of glucose, amino acids, and vitamins) media aseptically piped as much as $45 \mathrm{ml}$ into a $50 \mathrm{ml}$ sterile tube. Then, aseptically $5 \mathrm{ml} \mathrm{FBS}, 10 \mu \mathrm{l}$ fungizone, and $10 \mu \mathrm{l}$ gentamicin are added to the tube containing DMEM media. The mixture is then homogenized.

\section{Sample solution preparation}

The variation in a concentration of each test sample is based on the $\mathrm{LC}_{50}$ value. The $\mathrm{LC}_{50}$ value of each sample is used as a middle value. Then take two concentrations up and two concentrations down from the middle value. Aquades are sterilized using an autoclave to be used as a solvent. The crude ethanol extract was weighed as much as $0.001 \mathrm{~g}$ and dissolved with $10 \mathrm{ml}$ of sterile distilled water, to obtain a stock solution of crude ethanol extract with a concentration of $100 \mathrm{ppm}$. The crude ethanol extract stock solution was then diluted with sterile distilled water to obtain a crude ethanol extract test solution with concentrations of $3.5,7,14,28$, and $56 \mathrm{ppm}$.

The water fraction was weighed $0.01 \mathrm{~g}$ and dissolved with $10 \mathrm{ml}$ of sterile distilled water so that aqueous stock fraction with a concentration of $1,000 \mathrm{ppm}$ was obtained. The water fraction stock solution is then diluted with sterile distilled water until a water fraction test solution is obtained with concentrations of $37.5,75,150,300$, and $600 \mathrm{ppm}$. The sample ethyl acetate fraction was weighed as much as $0.02 \mathrm{~g}$ and dissolved first with $10 \mu \mathrm{DMSO}$, then dissolved with $10 \mathrm{ml}$ of sterile distilled water, so that a stock solution of ethyl acetate fraction was obtained with a concentration of 2,000 ppm. The stock solution of ethyl acetate fraction was then diluted with sterile distilled water to obtain a test solution of ethyl acetate fraction with concentrations of 100, 200, $400,600,800$, and 1,600 ppm.

The n-hexane fraction was weighed $0.01 \mathrm{~g}$ and dissolved first with $10 \mu \mathrm{DMSO}$. Then, it was dissolved with $10 \mathrm{ml}$ of sterile distilled water, to obtain a stock solution of n-hexane fraction with a concentration of $1,000 \mathrm{ppm}$. The stock solution of $\mathrm{n}$-hexane fraction was diluted with sterile distilled water until the n-hexane fraction test solution was obtained with concentrations of $37.5,75$, 150,300 , and $600 \mathrm{ppm}$.

\section{Antiproliferation activity test against MCM-B2 cells}

DMEM media aseptically piped as much as $45 \mathrm{ml}$ into a $50 \mathrm{ml}$ sterile tube. Then, aseptically $5 \mathrm{ml}$ FBS (the FBS contains very low level of antibodies and more growth factors, allowing for versatility in many different cell culture applications), $10 \mu \mathrm{l}$ fungizone, and $10 \mu \mathrm{l}$ gentamicin are added to the tube containing DMEM media. Culture media that have been made are homogenized and stored near Bunsen. Microplate culture was prepared and filled with $900 \mu \mathrm{l}$ of culture media into a microplate culture well. Each test solution was pipetted as much as $50 \mu \mathrm{l}$ into each microplate culture well. Negative control was made by adding $50 \mu \mathrm{l}$ of culture media to the microplate culture well which contained $900 \mu \mathrm{l}$ of culture media. Positive control was made by adding $50 \mu \mathrm{l}$ of $100 \mathrm{ppm}$ doxorubicin to a microplate culture well that contained $900 \mu$ l of culture media. Each concentration of each test solution, negative control, and positive control was carried out in triplo or three repetitions. Then, MCM-B2 cells were added to each $50 \mu \mathrm{l}$ microplate culture well. The microplate culture is wrapped in opaque paper and incubated for 3 days at $37^{\circ} \mathrm{C}$.

\section{MCM-B2 cell calculation}

The incubated microplate culture was removed from the incubator. Trypan blue is pipetted as much as $20 \mu \mathrm{l}$ into an empty microplate. MCM-B2 cells are homogenized and piped as much as $80 \mu \mathrm{l}$ into a microplate containing trypan blue. The mixture is homogeneous and put into a gold barometer. The calculation of the number of cells is done using a light microscope with a magnification of $100 \times$. After the cells are counted, an analysis is done with the SPSS program.

\section{RESULTS AND DISCUSSION}

\section{God's crown fruit preparation}

In this study, God's crown fruit used for the sample is the fruit flesh and seed shell. The sample was obtained from Lulut Village, Citeureup District, Bogor Regency. God's crown fruit has red skin with a fairly mature level of maturity. God's crown fruit $5.5 \mathrm{~kg}$ became simplisia $504.56 \mathrm{~g}$, which was used as a sample. Simplisia of God's crown fruit has a water content of $5.47 \%$. The yield of each sample is: crude ethanol extract at $10.74 \%$, n-hexane fraction at $3.03 \%$, ethyl acetate fraction at $11.84 \%$, and water fraction at $54.27 \%$.

God's crown fruit contains several photochemical compounds, such as alkaloids, saponins, flavonoids, tannins, and polyphenols (Astriyai et al., 2017). According to Mardany et al. (2016), flavonoids contained in God's crown fruit have the ability as an anticancer. God's crown fruit used for a sample has a fairly mature level and is red. God's crown fruit with sufficient maturity 
level has higher flavonoid content compared to the God's crown which is green and young (Wahyulianingsih et al., 2016). The older God's crown fruit decreases its phytochemical contents in concentration due to oxidation and decay processes (Sulistianto et al., 2004).

The water content was used to determine the success of drying the sample, determine the safety of the storage simplisia that has been made, and correct the extraction yield results. The simplisia water content $(5.46 \%)$ is smaller than the standard given by the Indonesian Herbal Pharmacopoeia, which is less than 10\% (Depkes, 2008). The water content value indicates that the sample is good to be used. The high water content will increase the potential for damage to the simplisia due to fungi and mold growth and reduce the extract biological activity in the storage period. Factors influencing the level of water content are simplisia drying time, simplisia metabolite compound content, air humidity, time to take materials, the amount of evaporation, and storage (Najib et al., 2017; Radusiene et al., 2012). The longer the simplisia drying process, the lower the water content (Najib et al., 2017). However, drying simplisia for too long can damage the active compounds contained in the simplisia.

The extraction of God's crown fruit flesh and seed shell was carried out using maceration and remuneration methods with $96 \%$ ethanol solvent. The advantage of using $96 \%$ ethanol as a solvent is that it is not toxic, noncorrosive, has a good absorption rate, only requires a little heat in the evaporation process, and is easily available (Lestari et al., 2015). The results obtained are yield of water fraction $>$ yield of crude ethanol extract $>$ yield of ethyl acetate fraction $>$ yield of $n$-hexane fraction. These results indicate that God's crown fruit contains many polar metabolites. The total amount of fraction yield did not reach $100 \%$ fractionated crude ethanol extract because the simplisia was allowed to stand for 3 days without using a shaking incubator to allow volatile compounds to be lost.

Fractionation is done to purify secondary metabolites that have been isolated in crude ethanol extracts with solvents that have different polarity properties. Fractionation with water solvents (distilled water) is carried out to obtain polar metabolite compounds, with n-hexane solvent to obtain metabolites that are nonpolar, and with ethyl acetate solvent to obtain metabolic compounds that are semipolar. Mae et al. (2002) stated that ethyl acetate has a hydroxyl group that is polar and an alkyl group that is nonpolar. Based on the ethyl acetate nature, the use of ethyl acetate in the fractionation is expected to be fraction compounds with different polarity levels in ethanol.

Phytochemical compounds isolated in crude ethanol extract samples are alkaloids, steroids, saponins, flavonoids, and tannins. Isolated compounds in the n-hexane fraction include alkaloids, steroids, saponins, and flavonoids (Sugiwati et al., 2009). Isolated compounds in the ethyl acetate fraction are flavonoids, alkaloids, tannins, saponins, terpenoids, and lignin (Astutiningsih et al., 2012). Isolated compounds in the water fraction include alkaloids, steroids, saponins, flavonoids, and tannins (Sugiwati et al., 2009).

\section{Cytotoxicity test}

All of the extract and fractions were used as samples in the cytotoxicity test. The parameter used was the death of Artemia salina larvae after each sample was given. The $\mathrm{LC}_{50}$ values of each sample are presented in Figure 2. The crude ethanol extract has the smallest $\mathrm{LC}_{50}$ value while the ethyl acetate fraction has the largest $\mathrm{LC}_{50}$ value.

Cytotoxicity tests were performed to determine the value of lethal concentration $50\left(\mathrm{LC}_{50}\right) . \mathrm{LC}_{50}$ value is the concentration value of the test sample that can have a toxic effect on $50 \%$ of test animals within 24 hours (Zestyadi et al., 2018). Test animals used in this test are Artemia salina larvae which are hatched in a laboratory with sea water and aerator. Artemia salina larvae are used as test animals because they have a high level of endurance (Tulangow et al., 2016). Larvae used are 48-hour-old larvae.

Cytotoxicity tests were carried out on each extract and fractions. Meyer et al. (1982) stated that the extract of a sample is classified as toxic if it has an $\mathrm{LC}_{50}$ value less than 1,000 ppm and is not toxic if an $\mathrm{LC}_{50}$ value more than $1,000 \mathrm{ppm}$. The smaller the $\mathrm{LC}_{50}$ value $(\leq 100 \mathrm{ppm})$, the more toxic it is. All test samples had $\mathrm{LC}_{50}$ values less than $1,000 \mathrm{ppm}$ which indicates that all samples were classified as toxic compounds. The results of cytotoxicity test showed that the crude ethanol extracts $\mathrm{LC} 50$ value $<\mathrm{LC}_{50}$ value of $\mathrm{n}$-hexane fraction $<\mathrm{LC}_{50}$ value of water fraction $<\mathrm{LC}_{50}$ value of ethyl acetate fraction. The crude ethanol extract has the smallest $\mathrm{LC}_{50}$ value indicating that ethanol extract is very toxic. Furthermore, the ethyl acetate fraction has the highest $\mathrm{LC}_{50}$ value indicating that the ethyl acetate fraction is less toxic than other extract and fractions. These results are in accordance with Puspita et al. (2019) that crude ethanol extract and n-hexane fraction have a potential as toxic compounds.

According to Pasilala et al. (2016), $\mathrm{LC}_{50}$ value is inversely proportional to the level of bioactivity of a sample. The smaller the $\mathrm{LC}_{50}$ value indicates the high level of bioactivity of a sample. Based on the cytotoxicity test, it can be analyzed that the crude ethanol extract sample has the highest bioactivity. These results are the same those by Puspita et al. (2019), i.e., the more polar the sample used, the more toxic it is. Then, the more polar solvents used for extraction and fractionation of the God's crown fruit, the more it provides a strong toxic effect. The more nonpolar solvents used for extraction and fractionation the God's crown fruit, the more it has a strong toxic effect. However, the use of semipolar solvents actually reduces the toxic effects on larvae. Based on this, it shows that polar and nonpolar metabolite compounds are more effective as antiproliferation.

\section{Antiproliferation activity test against MCM-B2 cells}

All extract and fractions of the God's crown were tested for antiproliferation activity against MCM-B2 cells. Variation in

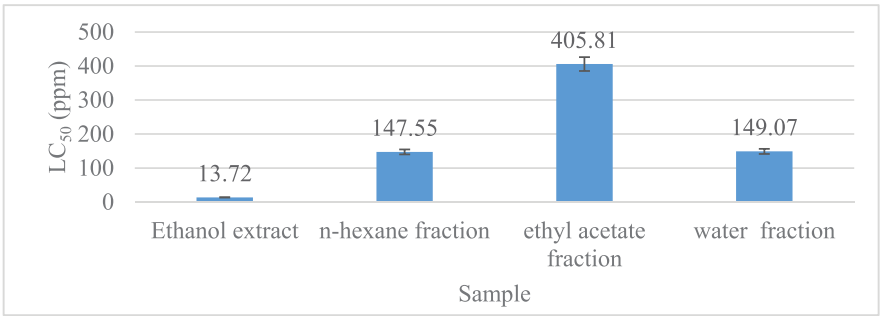

Figure 2. The $\mathrm{LC}_{50}$ value of God's crown fruit extract and fractions.

Remarks: The line bar indicates that mean values differ significantly based on Duncan's multiple range test $(p \leq 0.05)$ 
the concentration of each extract and fraction was made based on $\mathrm{LC}_{50}$ values. $\mathrm{LC}_{50}$ value is used as the concentration value of the concentration variation. A negative control containing only culture media and MCM-B2 cells was considered to have a proliferation activity of $100 \%$ and an antiproliferation activity of $0 \%$. A positive control containing $100 \mathrm{ppm}$ cancer drug (doxorubicin), DMEM growing media, and MCM-B2 cells was considered to have an antiproliferation activity of $31.2 \%$.

The antiproliferation activity of crude ethanol extract is presented in Figure 3. The crude ethanol extract, in general, can reduce MCM-B2 cell proliferation. The crude ethanol extract of 7-56 ppm has an antiproliferation activity (30.75\%-58.28\%) greater than $100 \mathrm{ppm}$ doxorubicin (31.2\%). The greater the concentration of the extract used, the greater the antiproliferation activity.

The antiproliferation activity of n-hexane fraction is presented in Figure 4. In general, n-hexane fraction can reduce MCM-B2 cell proliferation. The fraction of n-hexane of 150-600 ppm has an antiproliferation activity $(34.57 \%-46.06 \%)$ greater than $100 \mathrm{ppm}$ doxorubicin $(31.2 \%)$. The greater the concentration of n-hexane fraction used, the greater the antiproliferation activity.

The antiproliferation activity of ethyl acetate fraction is presented in Figure 5. Ethyl acetate fraction, in general, can reduce MCM-B2 cell proliferation. The 1,600 ppm ethyl acetate fraction has an antiproliferation activity $(32.46 \%)$ greater than 100 ppm doxorubicin (31.2\%). The greater the concentration of ethyl acetate fraction used, the greater the antiproliferation activity.

The antiproliferation activity of water fraction is presented in Figure 6. Water fraction, in general, can reduce MCM-B2 cell proliferation. Water fraction 75-600 ppm has an antiproliferation activity $(32.38 \%-52.84 \%)$ greater than $100 \mathrm{ppm}$ doxorubicin $(31.2 \%)$. The greater the concentration of the water fraction used, the greater the antiproliferation activity.

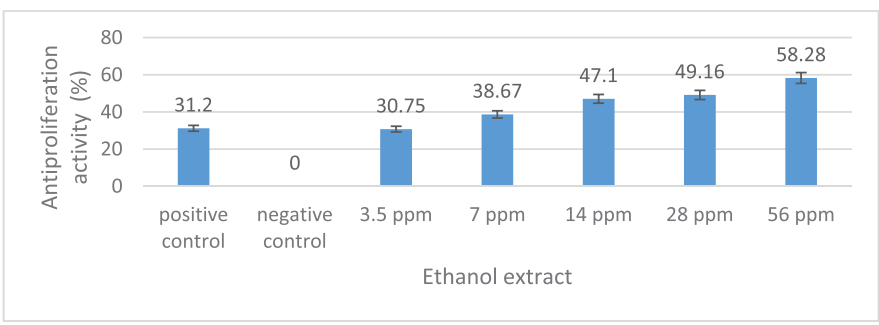

Figure 3. Antiproliferation activity of crude ethanol extract against MCM-B2 cells. Remarks: The line bar indicates that mean values differ significantly based on Duncan's multiple range test $(p \leq 0.05)$

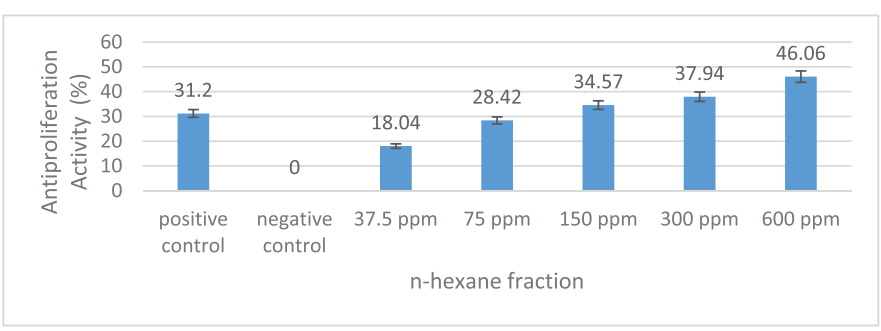

Figure 4. Antiproliferation activity of n-hexane fraction against MCM-B2 cells. Remarks: The line bar indicates that mean values differ significantly based on Duncan's multiple range test $(p \leq 0.05)$
The positive control used is doxorubicin. Doxorubicin $100 \mathrm{ppm}$ has $31.2 \%$ antiproliferation activity against MCM-B2 cells. Doxorubicin is an anthracycline synthesis drug used for chemotherapy in cancer patients (Yun et al., 2019). The mechanism of action of doxorubicin as an anticancer is to do damage to the DNA of cells exposed to cancer. Doxorubicin is able to inhibit nucleotide replication which involves inhibition of topoisomerase II (Yoneda and Cross 2010; Yun et al., 2019). Although it has been widely used as an anticancer, the use of doxorubicin is limited. Doxorubicin dose limitation is done to prevent cardiac toxicity (Yun et al., 2019). In addition, doxorubicin can cause several side effects such as dry lips, hair loss, nausea, vomiting, and heart problems (Atiqoh et al., 2011).

Increasing the concentration of each crown God's test sample is directly proportional to the increased antiproliferation activity of MCM-B2 cells. The fractionation of crude ethanol extract extraction aims to isolate secondary metabolite compounds from crude ethanol extract based on their level of polarity (Mae et al., 2002). The results of the number of MCM-B2 cells observed showed that crude ethanol extract had the highest percentage of antiproliferation activity compared to all fractions. The percentage of antiproliferation activity of crude ethanol extract is test samples $>$ water fraction $>$ n-hexane fraction $>$ ethyl acetate fraction. The more polar the metabolites of the crown God's test sample, the more antiproliferation activity potential of $50 \%$ MCM-B2 cells. The results of antiproliferation activity are directly proportional to the results of cytotoxicity.

The antiproliferation activity of $3.5 \mathrm{ppm}$ crude ethanol extract was not significantly different from doxorubicin $100 \mathrm{ppm}$ (Fig. 3). This shows that $3.5 \mathrm{ppm}$ crude ethanol extract has the potential equivalent to $100 \mathrm{ppm}$ doxorubicin. The crude ethanol extract $56 \mathrm{ppm}$ has an antiproliferation activity of MCM-B2 cells more than $50 \%$. This shows the excellent antiproliferation potential

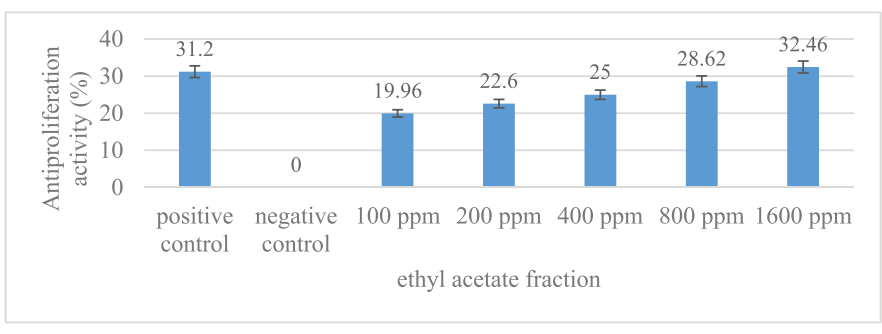

Figure 5. Antiproliferation activity of ethyl acetate fraction against MCM-B2 cells. Remarks: The line bar indicates that mean values differ significantly based on Duncan's multiple range test $(p \leq 0.05)$

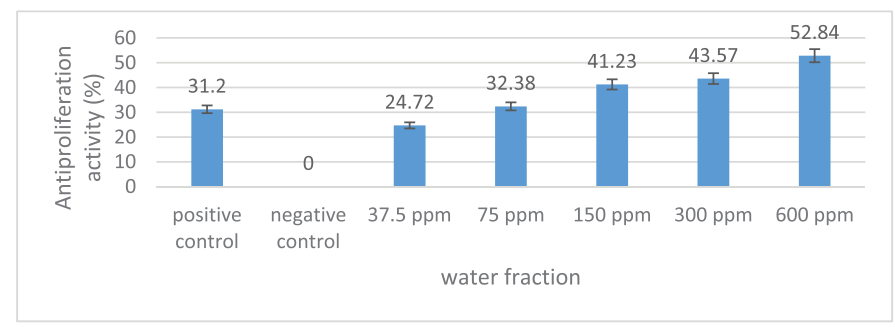

Figure 6. Antiproliferation activity of water fraction against MCM-B2 cells. Remarks: The line bar indicates that mean values differ significantly based on Duncan's multiple range test $(p \leq 0.05)$ 
of crude ethanol extract. Very small concentrations of crude ethanol extract of God's crown fruit can inhibit the proliferation of MCM-B2 cells. Factors that influence the efficiency of crude ethanol extract as antiproliferation are crude ethanol extract containing more and more complex polar metabolite compounds compared to fraction yield, and the crude ethanol extract has synergistic activity among phytochemical compounds in crude ethanol extract (Sugiwati et al., 2009).

The antiproliferation activity of $75 \mathrm{ppm}$ water fraction was not significantly different from doxorubicin 100 ppm (Fig. 6). This shows that the fraction of water with lower concentrations has the same potential as doxorubicin. Water fraction $600 \mathrm{ppm}$ has the antiproliferation activity of MCM-B2 cells more than $50 \%$ $(p \leq 0.05)$.

This shows the antiproliferation activity of large water fractions when the concentration is enlarged up to 6 times doxorubicin.

The antiproliferation activity of $14 \mathrm{ppm}$ n-hexane fraction was not significantly different from doxorubicin 100 ppm (Fig. 4). This shows that the fraction of n-hexane with lower concentrations has the same potential as doxorubicin. However, the maximum concentration of $n$-hexane fraction does not have MCM-B2 cell antiproliferation activity more than $50 \%$.

The antiproliferation activity of 1,600 ppm ethyl acetate fraction was not significantly different from doxorubicin $100 \mathrm{ppm}$ (Fig. 5). The maximum concentration of ethyl acetate fraction does not have MCM-B2 antiproliferation activity more than $50 \%$. Mae et al. (2002) stated that fractionation with ethyl acetate can bind more secondary metabolite compounds because ethyl acetate has polar and nonpolar groups. However, the results of testing the samples of ethyl acetate fraction had the smallest antiproliferation activity of MCM-B2 cells. This shows that the complex compound from the fruit of the God's crown does not have an effective role as an antiproliferation of MCM-B2 cancer cells.

Pasilala et al. (2016) stated that the fractionation samples obtained a single secondary metabolite compound. Single secondary metabolite compounds do not have synergistic cooperation without the presence of other secondary metabolites, so cytotoxicity is reduced. Synergistic effect is cytotoxicity caused combination compounds. The results are comparable with this study, namely crude ethanol extract of cytotoxicity is greater than all sample fractions.

Syahrir et al. (2016) stated that metabolite compounds in the fraction have a synergistic or antagonistic effect. Antagonistic effect is the opposite effect that causes a decrease in cytotoxicity when phytochemical compounds act together. The ethyl acetate fraction contains phytochemical compounds that are polar and nonpolar. This is thought to cause antagonistic effects so that the ethyl acetate fraction has the lowest antiproliferation activity value compared to other test samples.

The crude ethanol extract of God's crown fruit contains secondary metabolites of alkaloids, saponins, flavonoids, tannins, and polyphenols. Sugiwati et al. (2009) stated that the secondary metabolite compounds in crude ethanol extract were mostly flavonoids, alkaloids, and tannins. Puspita et al. (2019) stated that alkaloids have an anticancer function by inducing apoptosis in the extrinsic pathway. Then, flavonoids can stimulate enzyme activity so that it can induce apoptosis, antiproliferation, and angiogenesis of cancer cells (Astriyai et al., 2017; Ismaryani et al., 2018).
Flavonoids work through the mechanism of activating the apoptotic pathway in cancer cells by acting as an oxidant. Apoptosis of cancer cells by flavonoids will result in the fragmentation of cell DNA. Fragmentation occurs due to the release of proximal DNA chains by reactive oxygen compounds. Reactive oxygen compounds include hydroxyl radicals. The formation of hydroxyl radical compounds occurs through the redox reaction $\mathrm{Cu}$ (II) which is driven by flavonoids from extra cells, cell nuclei, and chromatin. The second mechanism of flavonoids plays a role in inhibiting tumor or cancer proliferation by inhibiting protein kinase activity. The inhibition of protein kinase activity causes inhibition of the signal transduction pathway from the cell membrane to the cell nucleus. The mechanism of the third flavonoid is by inhibiting the tyrosine kinase receptor activity which increases and plays a role in the growth of cancer cell malignancy (Mardany et al., 2016). Ismaryani et al. (2018) stated that the mechanism of flavonoids as anticancer is by inactivating carcinogens, antiproliferation, inhibition of cell cycle, induction of apoptosis, differentiation, and inhibition of angiogenesis.

\section{CONCLUSION}

The results of cytotoxicity test were comparable to the results of antiproliferation activity test in all samples. Polar compounds are more effective to be used to extract the metabolites of God's crown as antiproliferation. The crude ethanol extract of God's crown fruit has a better antiproliferation activity compared to the fractions and doxorubicin. The crude ethanol extract is effectively used as an alternative treatment for breast cancer.

\section{ACKNOWLEDGMENT}

The authors are thankful to the Faculty of Sciences and Faculty of Veterinary Medicine, IPB University, Indonesia, for all laboratory facilities and providing cancer-derived cell lines.

\section{CONFLICT OF INTEREST}

Authors declare that they have no conflicts of interest.

\section{REFERENCES}

Agustinisari I, Zakaria FR. Pengaruh ekstrak rimpang jahe (Zingiber Officinale Roscoe) segar dan tunas jahe terhadap proliferasi beberapa alur sel kanker. Jurnal Penelitian Pascapanen Pertanian 2019; 3(1):50-9. Available via https://dx.doi.org/10.21082/jpasca.v3n12006.50-59

Astriyai W, Surjowardojo P, Susilorini TE. Daya hambat ekstrak buah mahkota dewa (Phaleria macrocarpa L.) dengan pelarut etanol dan aquades terhadap bakteri Staphylococcus aureus penyebab mastitis pada sapi perah. Jurnal Ternak Tropika 2017; 18(2):8-13. Available via https:// dx.doi.org/10.21776/ub.jtapro.2017.081.02.2

Astutiningsih C, Nuzulia F, Suprijono A. Isolasi dan identifikasi senyawa alkaloid buah mahkota dewa (Phaleria macrocarpa (Scheff.) Boerl) secara spektrofotometri Uv-Vis dan IR serta uji toksisitas akut terhadap larva Artemia salina Leach. Jurnal Farmasi Sains dan Komunitas 2012; 9(2):66-70. Available via https://dx.doi.org/10.24071/jpsc.9272

Atiqoh H, Wardani RS, Meikawati W. Uji antidiabetik infusa kelopak bunga rosela (Hibiscus sabdariffa Linn.) pada tikus putih jantan galur wistar yang diinduksi glukosa. Jurnal Kesehatan Masyarakat Indonesia 2011; 7(1):43-50.

Dawud F, Bodhi W, Lolo WA. Uji efek antiinflamasi ekstrak etanol kulit mahkota dewa (Phaleria macrocarpa Boerl.) terhadap edema kaki tikus putih jantan. Pharmacon 2014; 3(1):8-14.

Departemen Kesehatan [Depkes]. Farmakope Herbal Indonesia Edisi 1. Departemen Kesehatan Republik Indonesia, Jakarta, Indonesia, 2008. 
Ismaryani A, Salni, Setiawan A, Triwani T. Aktivitas sitotoksik, antiproliferasi dan penginduksi apoptoksis daun salung (Psychotria viridiflora Reinw. ex. Blume) terhadap sel kanker serviks HeLa. Jurnal Ilmu Kefarmasian Indonesia 2018; 16(2):206-13. Available via https://dx.doi. org/10.35814/jifi.v16i2.528

Lestari T, Nurmala A, Nurmalasari M. Penetapan kadar polifenol dan aktivitas antibakteri ekstrak etanol daun sintrong (Crassocephalum crepidiodes (Benth.) S.moore). Jurnal Kesehatan Bakti Tunas Husada 2015; 13(1):107-2.

Lukmandaru G, Gazidy AA. Bioaktivitas dan aktivitas antioksidan ekstrak batang mahkota dewa. Jurnal Ilmu Teknologi Kayu Tropis 2016; 14(2):114-26.

Ma'aruf FA, Adiwijaya, Wisesty UN. Analisis pengaruh metode reduksi dimensi minimum redundancy maximum relevance pada klasifikasi kanker berdasarkan data microarray menggunakan classifier support vector machine. E-Proc Eng 2018; 5(1):1499-506.

Mae SHW, Subagus W, Gemini A, Ika RA, Veronika K. Toxic effect evaluation of fractions obtained from the leaves of Mahkotadewa [Phaleria macrocarpa (Scheff.) Boerl.] methanol extract by brine shrimp lethality test. J Trad Med 2002; 7:29-33.

Malik MZ, Kadar K, Patellongi I. Compliance level of supportive care needs among breast cancer survivor at Ibnu Sina Hospital Makasar. Indonesian Contemp Nur J 2018; 1(2):68-75.

Mardany MP, Chrystomo LY, Karim AK. Skrining fitokimia dan uji aktivitas sitotoksik dari tumbuhan sarang semut (Myrmecodia beccarrii Hook.f.) asal Kabupaten Marauke. Jurnal Biologi Papua 2016; 8(1):13-22. Available via https://dx.doi.org/10.31957/jbp.41

Martono B, Falah S, Nurlaela E. Aktivitas antioksidan teh varietas GMB 7 pada beberapa ketinggian tempat. Jurnal Tanaman Industri dan Penyegaran 2016; 3(1):53-60.

Meyer BN, Ferrigni NR, Putnam JE, Jacobsen LB, Nichols DE, McLaughlin LJ. Brine Shrimp: a convenient general bioassay for active plant constituents. J Med Plant Res 1982; 45:31-4. Available via https:// dx.doi.org/10.1055/s-2007-971236

Najib A, Malik A, Ahmad AR, Handayani V, Syarif RA, Waris R. Standarisasi ekstrak air daun jati belanda dan teh hijau. Jurnal Fitofarmaka Indonesia 2017; 7(4):241-45. Available via https://dx.doi.org/10.33096/jffi. v4i2.268

Pasilala FB, Daniel, Saleh C. Uji toksisitas (Brine Shrimp Lethality Test) dan aktivitas antioksidan dari daun sintrong (Crassocephalum crepidiodes) dengan metode 2,2-diphenyl-1-picrylhidrazil (DPPH). Jurnal Kimia Mulawarman 2016; 14(1):13-18.

Priosoeryanto BP, Tateyama S, Yamaguchi R, Uchida K. Establishment of cell line (MCM-B2) from a benign mixed tumour of canine mammary gland. Res Vet Sci 1995; 58:272-6. Available via https:// dx.doi.org/10.1016/0034-5288(95)90116-7

Puspita R, Bintang M, Priosoeryanto BP. Antiproliferative activity of longan (Dimocarpus longan Lour.) leaf extracts. J Appl Pharm Sci 2019; $9(05): 102-6$.

Radusiene J, Karpaviciene B, Stanius Z. Effect of external and internal factors on secondary metabolites accumlation in st. John's worth. Botanica Lithuanica 2012; 18(2):101-8. Available via https://dx.doi. org/10.2478/v10279-012-0012-8

Ramadhan A, Lubis YM, Nasution SW, Nasution SLR, Girsang E, Nasution AN. Uji efektivitas ekstrak buah kurma (Phoenix dactylifera) dan ekstrak buah mahkota dewa (Phaleria macrocarpa) sebagai nefroprotektor terhadap tikus yang diinduksi paracetamol. Jurnal Farmacia $2019 ; 1(1): 8-15$.
Rinayanti A, Dewanti E, Adelia MH. Uji efek antiinflamasi fraksi air daun mahkota dewa (Phaleria macrocarpa (Shecff.) Boerl.) terhadap tikus putih (Rattus norvegicus L.). Pharm Sci Res 2014; 1(2): 78-85. Available via https://dx.doi.org/10.7454/psr.v1i2.3324

Rohyami Y. Penentuan kandungan flavonoid dari ekstrak methanol daging buah mahkota dewa (Phaleria macrocarpa scheff boerf) Jurnal Penelitian dan Pengabdian 2008; 5(1):1-16.

Setyawan IA, Syukri Y, Anshory H. Pengaruh suhu pengeringan spary dryer terhadap sifat fisik dan aktivitas antioksidan tablet ekstrak buah mahkota dewa (Phaleria macrocarpa Boerl.). J Sci Appl Technol 2018; 2(1):34-9. Available via https://dx.doi.org/10.35472/281428

Sugiwati S, Setiasih S, dan Afifah E. Antihyperglycemic activity of the mahkota dewa [Phaleria macrocarpa (Scheff.) Boerl.] leaf extracts as an alpha-glucosidase inhibitor. Makara Kesehatan 2009; 13(2):74-8.

Sulaiman FH, Yulianti K, Serviana H. Model matematika terapi kanker menggunakan kemoterapi, imunoterapi, dan biochemotherapy. Jurnal Eurekamatika 2019; 7(1):1-10.

Sulistianto DE, Harini M, Handajani NS. Pengaruh pemberian ekstrak buah mahkota dewa (Phaleria macrocarpa (Scheff) Boerl) terhadap struktur histologis hepar tikus putih (Rattus norvegicus L.) setelah perlakuan dengan karbon tetraklorida (CC14) secara oral. Biosmart 2004; 6(2):91-8.

Sunaryo M. Sosialisasi deteksi kanker payudara dengan teknik sadari pada wanita pekerja. Comm Devel J 2018; 2(1):33-9.

Syahrir NHA, Afendi FM, Susetyo B. Efek Sinergis Bahan Aktif Tanaman Obat Berbasiskan Jejaring dengan Protein Target. Jurnal Jamu Indonesia 2016; 1(1):35-46.

Tulangow LF, Queljoe ED, Simbala H. Identifikasi senyawa fitokimia dan uji toksisitas dengan metode BSLT ekstrak etanol bunga ubu-ubu (Hibiscus rosa-sinensis L.) dari maluku utara. Pharmacon 2016; 5(3):175-85.

Wahyulianingsih W, Handayani S, Malik A. Penetapan kadar flavonoid total ekstrak daun cengkeh (Syzygium aromaticum (L.) Merr dan Perry. Jurnal Fitofarmaka Indonesia 2016; 3(2):188-93. Available via https://dx.doi.org/10.33096/jffi.v3i2.221

Wardhani AD, Saraswati LD, Adi MS. Gambaran pengetahuan remaja putri tentang sadari dan praktik pemeriksaan payudara sendiri. Jurnal Kesehatan Masyarakat 2016; 5(1): 180-6.

Yoneda KY, Cross CE. The pulmonary Toxicity of anticancer agents. University of California, California, CA, 2010

Yun UJ, Lee JH, Shim J, Yoon K, Goh SH, Yi EY, Ye SK, Lee JS, Lee H, Park J, Lee IH. Anti-cancer effect of doxorubicin is mediated by downregulation of HMF-Co A reductase via inhibition of EGFR/Src pathway. Lab Invest 2019; 1:1-6. Available via https://dx.doi.org/10.1038/ s41374-019-0193-1

Zestyadi IR, Solikhin S, Yasin N. Toksisitas ekstrak buah mahkota dewa (Phaleria papuena Warb.) terhadap ulat gayak (Spodoptera litura F.) di laboratorium. Jurnal Agroteknologi Tropika 2018; 6(1):21-5. Available via https://dx.doi.org/10.23960/jat.v6il.2528

\section{How to cite this article:}

Hasim H, Kurniawati SO, Priosoeryanto BP, Faridah DN, Puspita R. Antiproliferation activity of God's crown fruit (Phaleria macrocarpa) extract and fractions against MCM-B2 breast cancer cells. J Appl Pharm Sci, 2020; 10(03):052-058. 